\title{
Climate and pedological factors of slump development on a Transylvanian example
}

\author{
Csaba FAZAKAS \\ email: fazakascs@ms.sapientia.ro \\ Sapientia Hungarian University of Transylvania, \\ Faculty of Technical and Human Sciences, Tg. Mures \\ Department of Horticulture
}

\begin{abstract}
Areas endangered by slump formation in the Măgherani Basin, part of the Nirajului Hills (Romania), are studied in the present paper. Time periods considered dangerous regarding the development of slumps and the degree of risk were determined. Pedological conditions of the model area are assessed based on field and laboratory measurements, self-constructed maps and literature data. These factors could have contributed to the formation of slump phenomena in the model area.
\end{abstract}

Keywords: slump, landslide susceptibility, rock oversaturation, Măgherani Basin

\section{Introduction}

Slumps - a special type of mass movement resembling the characteristic forms of the Transylvanian Plains (Câmpia Transilvaniei) - are also characteristic of the Măgherani Basin. The clay-marl-sand stratification of the basin and its piedmont basin character help the formation of these landslide types. Landslide sensitivity or landslide susceptibility means the probability in space and time of landslide formation [8] (Varnes 1984). The present paper assesses the susceptibility of slump formation regarding temporal and spatial differences. Temporal risk of the formation of slumps depends on climatic conditions. Correlation between precipitation and the formation of landslides is discussed in numerous publications: Chleborad et al. (2006), Coe et al. (2004), Zezere et al. (2005). Some of these describe specific cases, others 
analyse statistic relationships in order to establish correlation models or forecast models on the basis of precipitation quantity [1] [3] [9]. Ujvári and Buz (1973) recommend the including of the term "rock oversaturation" [7] in the gravitation movement calculations of slopes. Spatial susceptibility depends on the pedological conditions. Factors of spatial susceptibility are regarded to be the preconditions of landslides. Transformation of natural conditions by man (e.g., deforestation, cultivation) increases the probability of slump formation (Swanson \& Dryness 1975, Chung et al. 1995, Montgomery et al. 1998) [6], [2], [5].

\section{Material and methods}

The research area is located in the administration area of Şilea Nirajului and Măgherani settlements, $38 \mathrm{~km}$ from the town of Târgu Mureş, in the foreground of the Gurghiu Mountains in the NE margin of the Transylvanian Basin (Fig 1).

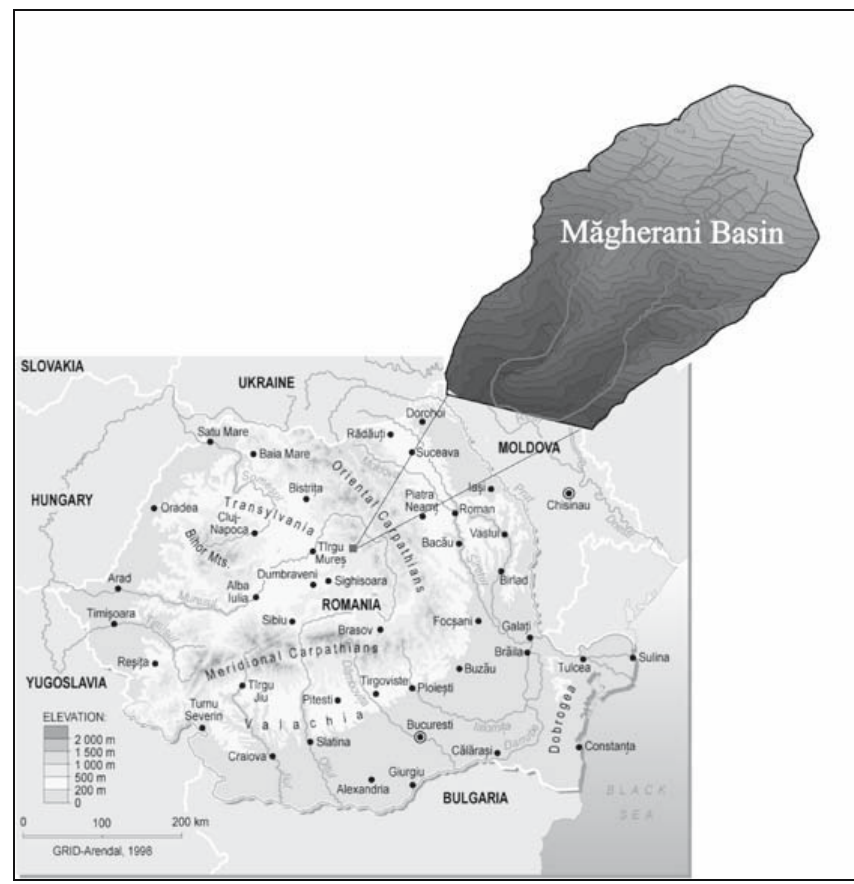

Figure 1: Location of the Măgherani Basin in Romania 
This special type of mass movement, slump, is present in several areas of the Măgherani Basin, and extended areas are denuded due to its effects becoming unsuitable for cultivation.

Precipitation and temperature data concerning the year of the development of the slump at Şilea Nirajului (1999) and the two preceding years (1997 and 1998) were acquired as oversaturation triggering the slump could have taken place only in these years. Average monthly precipitation and monthly average temperature distributions are presented graphically (Fig. 2 and 3).

In order to study the pedological conditions of slump formation, the 1:10000 scaled cadastral and contour maps and the 1:25000 scaled military topographic maps were applied.

Soil conditions contributing to the formation of slumps were surveyed.

Field study of the soils was performed based on $15 \mathrm{dug}$ soil profiles and 40 control drillings. The extension of the pedons was controlled based on analyses carried out using a Pürckhauer drilling rod. In the course of the pedological survey of the area, 8 soil types were identified. Samples were taken from each soil unit and analysed in laboratory.

Physical and chemical properties of the soils were analysed in the laboratory of the Mureş County Office for Pedology and Agrochemistry, applying the following methods: $\mathrm{pH}$ - potentiometric method; $\mathrm{CaCO}_{3}$ determination calcimeter with Scheibler's method; SB (basoid cation exchange capacity) Kappen's method; SH (hydrogen ion exchange capacity) - Cernescu's method; grain-size distribution - Kacinski's method.

Special attention was paid to the physical soil properties determination (especially clay fraction) and to determine the presence and quantity of a material cementing the grains, as these properties determine the most the role of soils in the formation of slumps.

Mineralogical investigations were not possible; therefore, the published results of other scientists were studied.

\section{Results and discussion}

The graph presenting the yearly distribution of average temperatures (Fig. 2) reveals that the study area was characterized by high positive monthly average temperatures from March 1999 on, resulting in snowmelt, earlier than in other years. 


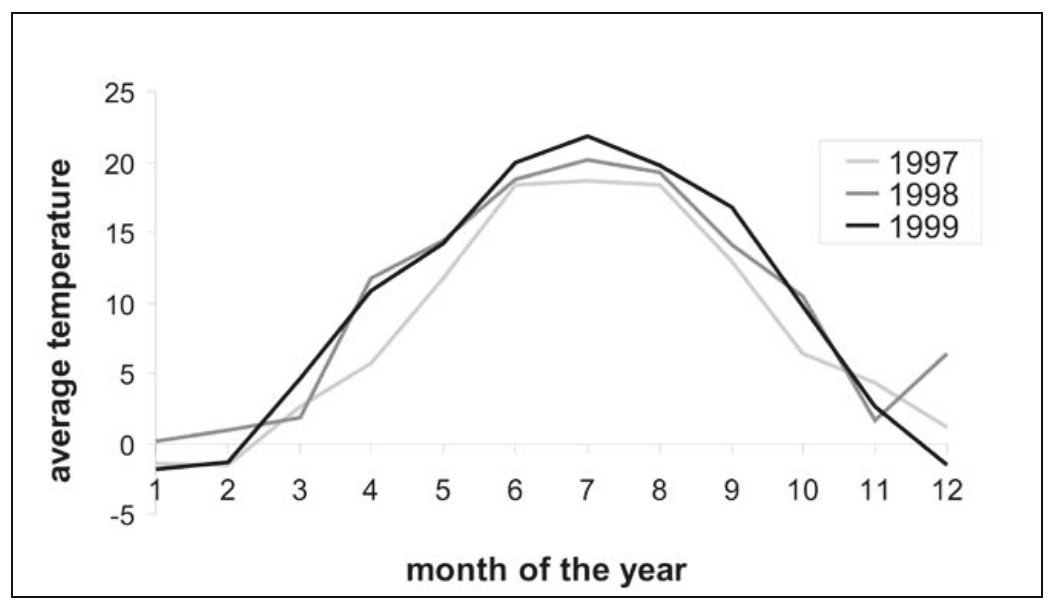

Figure 2: Annual distribution of average temperatures (1997, 1998, 1999)

On the graph showing the monthly precipitation values (Fig. 3), the amount of precipitation in the area in 1999 is compared to the amount of precipitation in the two previous years. The comparison reveals that although there was no record amount of precipitation in 1999, it exceeded $84 \mathrm{~mm} / \mathrm{m}^{2}$ - representing a great amount of precipitation in our region - in every month from April until July.

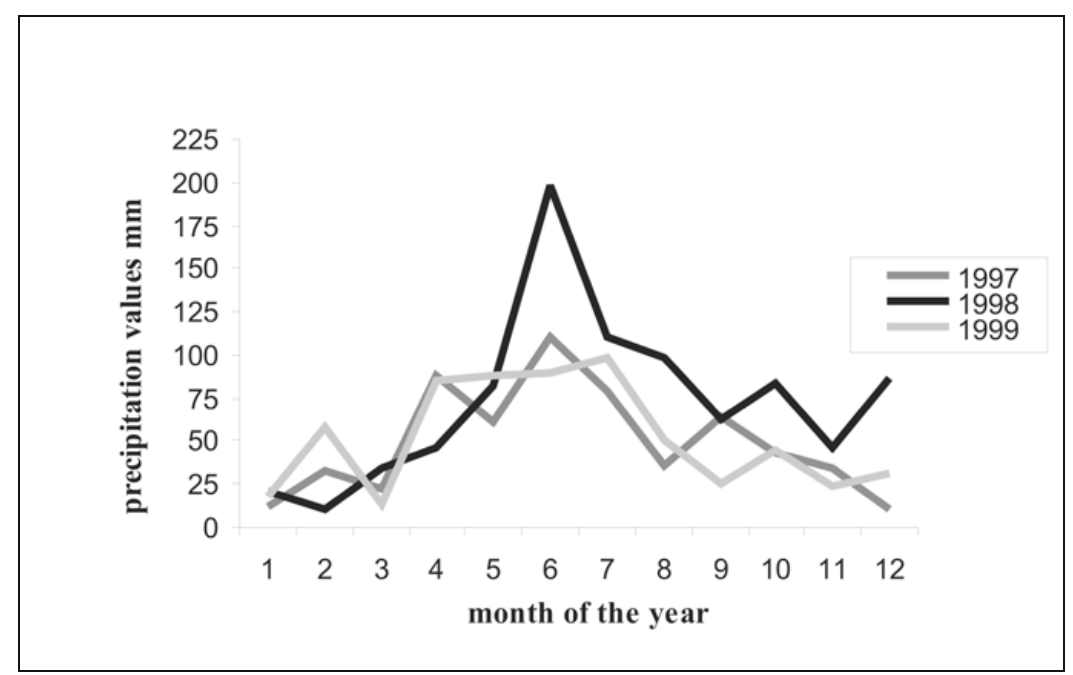

Figure 3: Distribution of the average monthly precipitation in the years 1997, 1998 and 1999 
From May 1998, a period of vast precipitation started. Between May and October, and then in December as well, the amount of precipitation exceeded the average (Table 1) characteristic of our region for many years. The difference was 40-50 $\mathrm{mm}$ and even $120 \mathrm{~mm}$ in June. The second half of 1998 was characterized by precipitation excess.

Table 1: Comparison of the seasonal average precipitation of 1998 to the average of many years

\begin{tabular}{cccc}
\hline Months & $\begin{array}{c}\text { Average of many } \\
\text { years }(\mathrm{mm})\end{array}$ & $\begin{array}{c}\text { Average of } \\
1998\end{array}$ & $\begin{array}{c}\text { Difference } \\
(\mathrm{mm})\end{array}$ \\
\hline VI-XII & 408.5 & 685.1 & +276.6 \\
IX-XII & 159.4 & 267.7 & +108.3 \\
\hline
\end{tabular}

Knowing the formation period of large slumps, the precipitation data, the period of snowmelt and the period of rock oversaturation, the graph of the risk of landslide formation was prepared (Fig. 4).

It was determined that the time period of lithological oversaturation lasts from January until May. Within this, the time period of the most frequent slope mobility lasts from March until May, i.e. it is connected to the time period following snowmelt. In June, which has the greatest precipitation, the mobility of the slopes is moderate while the time periods of the most stable slopes are August, October and November.

Water accumulated in the soil was unable to evaporate due to the low temperature in autumn, it was frozen in winter and then, as thawing in spring, it prepared the formation of the slump.

The Măgherani Basin is a small landscape unit that can be clearly defined geomorphologically. Its inner part, the $350-400 \mathrm{~m}$ high basin bottom is bordered from the valley of the Niraj river on the NW and W and from the valley of the Târnava Mică river on the S and SE by a mountain range rising over 500 $\mathrm{m}$. On the NE and E, the border is formed by the Bichiş Mountain (1079 m). Streams running off the Bichiş Mountain exposed the monoclinal Pannonian strata in strike orientation and formed asymmetric valleys by landslides sliding down along the strata beds.

Ridges and ravines forming on the slopes developed over centuries and thousands of years forming wide valleys eventually. These processes are going on even today in a landscape where the ratio of slopes steeper than $5 \%$ gives more than $90 \%$ of the entire land; thus, current slope processes give a strong mark on land use, especially from agricultural point of view. 


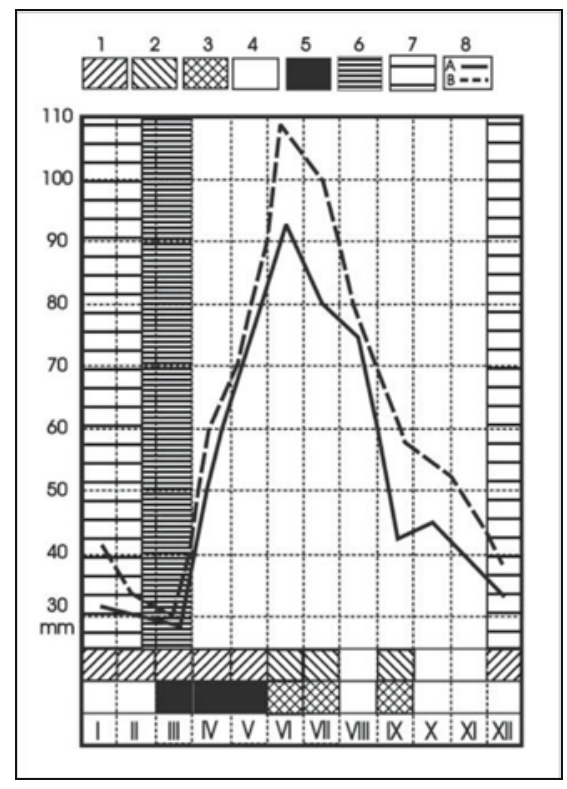

Figure 4: Graph showing the periods considered dangerous regarding slump formation and the degree of risk: 1 - time period of lithological oversaturation, 2 - time period of random, temporary oversaturation, 3 - time period of the moderate mobility inclination of slopes, 4 - time period of the maximum stability of slopes, 5 - time period of the greatest mobility inclination of slopes, 6 - time period of the final melt of snow cover, 7 - repeating melt period of snow cover, 8 - average precipitation amounts: A - in Târgu-Mureş and B Măgherani

The Măgherani Basin cannot be regarded as geomorphologically stable due to the presence of several clay and marl layers in the Pannonian strata. The area is destined for slump-type mass movement development, geologically due to the following conditions:

- Clay and clay-marl strata have sheet-like thin stratification. The densely fractured character and loose internal structure of these (bedding planes form a poorly resistant surface) enable the filtration of precipitation water into deeper horizons.

- Thick-bedded slope sediments lay on the rocks forming the slopes with slope angle and petrographic discordance that has a significant role in the formation of landslides. 
The geological conditions of the area determine the character and the temporal change of the relief pattern, the sloping conditions, the steepness, orientation and shape, etc. of the slopes, this way influencing the suitability of the land for the formation of mass movements. Geological conditions, however, also influence the physical-chemical properties of the soils. Grain-size distribution of the soils, their clay content and $\mathrm{pH}$ reflect the properties (determinative regarding slump formation) of the soil-forming sedimentary rocks.

Studying the soil cover of the area, it has become clear that the properties of the thick Pannonian slope sediments are favourable for the formation of slump-type mass movements. Based on the grain-size distribution of the soil, they are classified into the clayey silt - silt - silty clay texture types (Table 2).

Table 2: Soil types in the Măgherani Basin and their profile descriptions from grain-size distribution point of view

\begin{tabular}{|c|c|c|c|c|c|c|c|}
\hline \multirow[b]{2}{*}{ Nr. } & \multirow[b]{2}{*}{ Soil type } & \multirow[b]{2}{*}{ Horizon } & \multirow[b]{2}{*}{ Depth/cm } & \multicolumn{4}{|c|}{ Texture } \\
\hline & & & & $\begin{array}{c}\text { Coarse } \\
\text { sand } \\
2.0-0.2 \\
\mathrm{~mm}\end{array}$ & $\begin{array}{c}\text { Fine } \\
\text { sand } \\
0.2-0.02 \\
\text { mm }\end{array}$ & $\begin{array}{c}\text { Silt } \\
0.02- \\
0.002 \\
\mathrm{~mm}\end{array}$ & $\begin{array}{c}\text { Clay } \\
<0.002 \\
\mathrm{~mm}\end{array}$ \\
\hline \multirow{5}{*}{1} & \multirow{5}{*}{ Stagnic Luvisols } & Aa1 & $0-25$ & 3.2 & 31.9 & 34.0 & 30.9 \\
\hline & & $\mathrm{Aa} 2$ & $25-40$ & 2.9 & 34.4 & 33.9 & 28.8 \\
\hline & & $\mathrm{Bt}(\mathrm{B}) \mathrm{g}$ & $45-55$ & 4.3 & 27.4 & 31.0 & 36.2 \\
\hline & & Btg & $80-100$ & 2.7 & 23.2 & 30.2 & 43.8 \\
\hline & & Btg2 & $130-180$ & 3.8 & 19.4 & 24.2 & 52.6 \\
\hline \multirow{2}{*}{2} & \multirow{2}{*}{ Distric Cambisols } & $\mathrm{A}$ & $5-30$ & 6.0 & 40.6 & 29.7 & 24.6 \\
\hline & & (B) & $40-100$ & 7.8 & 34.2 & 22.7 & 35.2 \\
\hline \multirow{3}{*}{3} & \multirow{3}{*}{$\begin{array}{l}\text { Colluvic Calcaric } \\
\text { Fluvisols }\end{array}$} & $\mathrm{Aa}$ & $0-20$ & 4.4 & 36.5 & 32.4 & 26.8 \\
\hline & & $A^{\prime}$ & $20-35$ & 5.8 & 36.2 & 29.5 & 28.4 \\
\hline & & A" & $50-80$ & 5.0 & 33.2 & 27.9 & 33.7 \\
\hline \multirow{3}{*}{4} & Colluvic Humic & A & $0-25$ & 8.0 & 26.2 & 28.1 & 37.5 \\
\hline & Calcaric Fluvisols & $\mathrm{AD}$ & $30-40$ & 1.2 & 24.4 & 36.0 & 38.5 \\
\hline & with mixed horizons & $\mathrm{D}$ & $70-100$ & 0.4 & 20.6 & 38.4 & 40.8 \\
\hline \multirow{3}{*}{5} & \multirow{3}{*}{ Calcaric Gleysols } & $\mathrm{A}(\mathrm{Go})$ & $5-15$ & 3.1 & 18.2 & 28.7 & 50.0 \\
\hline & & $\mathrm{A}(\mathrm{Gr})$ & $20-40$ & 5.9 & 15.0 & 29.5 & 49.6 \\
\hline & & $\mathrm{D}(\mathrm{Gr})$ & $80-90$ & 1.3 & 19.8 & 27.4 & 51.5 \\
\hline \multirow{4}{*}{6} & \multirow{4}{*}{$\begin{array}{l}\text { Stagnic Gleyic } \\
\text { Faeoziems }\end{array}$} & $\mathrm{Aa}$ & $5-20$ & 3.4 & 24.7 & 29.2 & 42.7 \\
\hline & & $A^{\prime}$ & $35-55$ & 0.6 & 21.9 & 32.0 & 45.5 \\
\hline & & $\mathrm{Bg}$ & $65-90$ & 1.3 & 24.5 & 30.0 & 44.4 \\
\hline & & $\mathrm{CBg}$ & $130-160$ & 2.6 & 33.0 & 32.2 & 32.2 \\
\hline \multirow{2}{*}{7} & Stagnic & $\mathrm{Ba}$ & $0-18$ & 13.1 & 52.2 & 14.3 & 20.4 \\
\hline & Regosol & B & $20-40$ & 6.9 & 40.5 & 21.6 & 31.0 \\
\hline \multirow{2}{*}{8} & Calcaric regosol & $\mathrm{C}$ & $0-22$ & 3.1 & 28.3 & 31.3 & 37.3 \\
\hline & affected by landslides & $\mathrm{D}$ & $30-60$ & 0.4 & 40.1 & 26.6 & 32.9 \\
\hline
\end{tabular}


In the marginal parts of the areas characterized by slumps, the unmoved slope masses are variably fine-textured from the surface towards greater depth dominated by clay and silt-clay grain-size.

The soil-forming rock in the area of the basin is clay marl, which is clay containing a significant amount of lime. The active clay fraction $(<0.002$ $\mathrm{mm}$ ) is dominated by hydrated mica, mostly swelling illite/montmorillonite and beidellite-type clay minerals in both the weathered and unweathered rocks. Repeated swelling (in wetter periods) and shrinking (in dry periods) prepare the soils for sliding down the slopes.

Clay in-wash horizons marked with $\mathrm{B}(\mathrm{t})$ in the soils of the area cause poor water balance. As a result, a significant portion of the soils (43\%) show pseudogleyic and gleyic characters. The hydromorphous character of the Stagnic Luvisols and the presence of the Stagnic Gleyic Faeoziems are the result of the soil-forming rock properties. Water filtrates very slowly into these soils. They are characterized by saturation with water filtrating parallel with the surface until late spring. Snowmelt following cold periods with excess precipitation and downpours in spring increases their slump-generating characters.

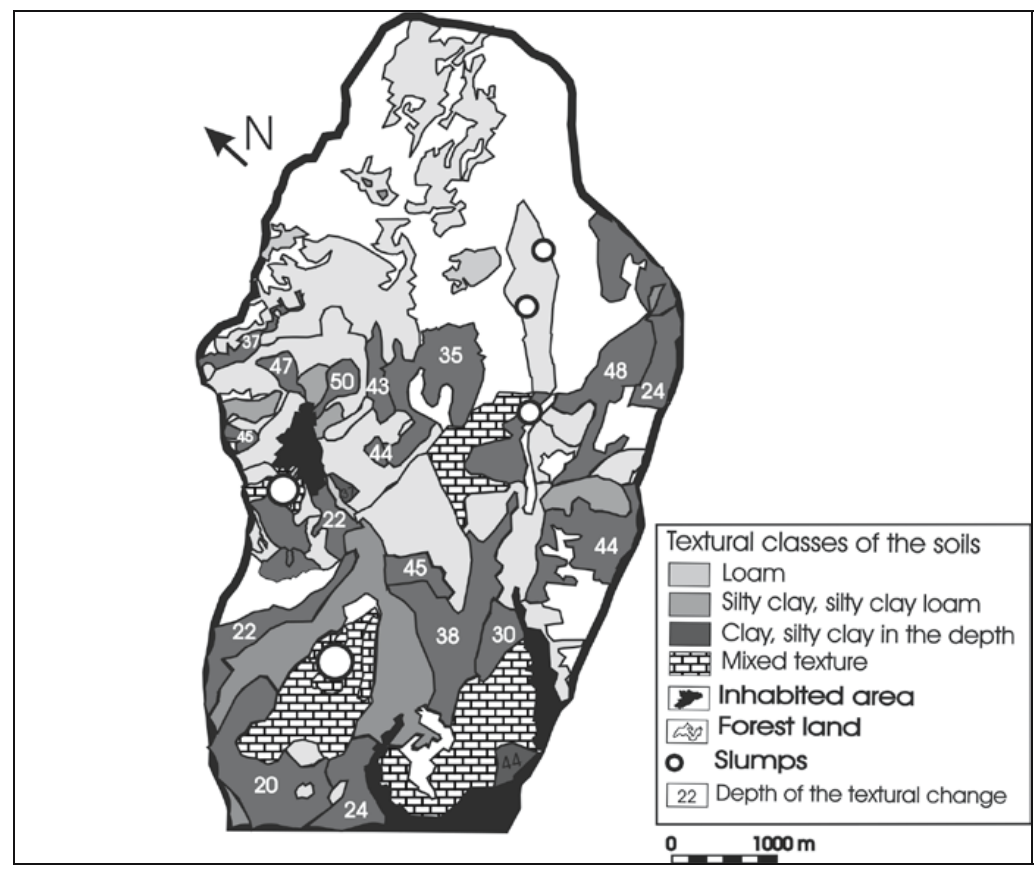

Figure 5: Textural classes of the soils in the Măgherani Basin (soils of areas covered by woods were not investigated) 
Determination of grain-size distribution of the samples in the area of the slumps is sometimes rather difficult due to the mixing of soil horizons. Strong dissectivity increases surface erosion. Material of various grain sizes washed from the surface is accumulated in irregular setting at the foot of the steep positive forms. In such cases, grain-size distribution is so variable even in small areas that it cannot be plotted on large-scale maps. These areas are marked as regions with mixed-textured soils. In the course of the laboratory analysis of the soils, the followings were experienced:

- Iron oxides are present only in small quantity in the soil-forming rocks; therefore, cementing of the grains is relatively poor.

- Significant amount of calcium carbonate (5-18\%) results in high $\mathrm{pH}$ (7.2-8.4). A significant portion of the soils in the area (around 60\%) therefore shows neutral or basic $\mathrm{pH}$.

There is a close correlation between the distribution of slumps and the $\mathrm{pH}$ of the soils. Practically, all slumps were formed in basic soils (Fig. 6).

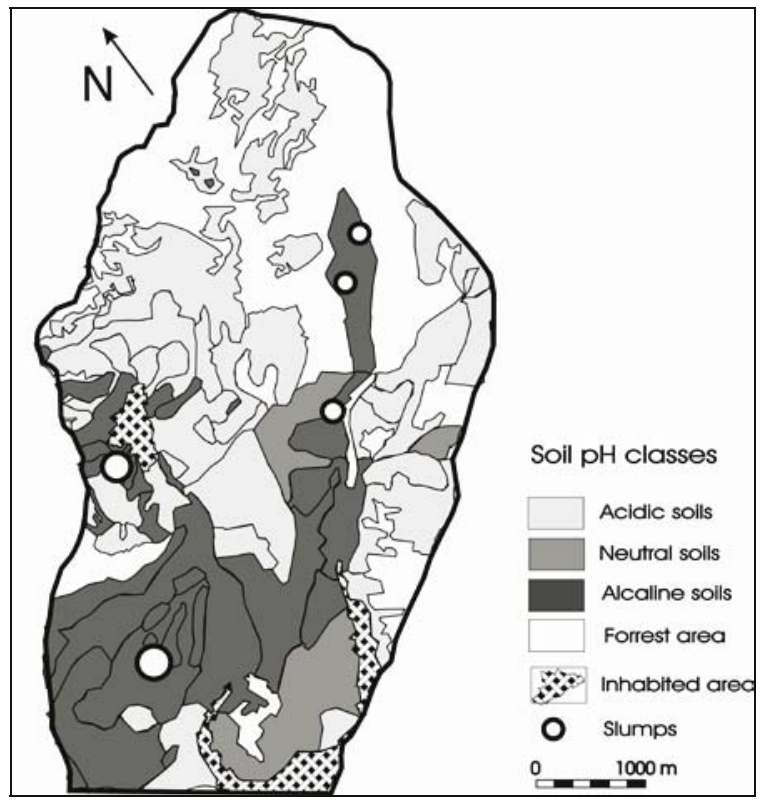

Figure 6: pH classes of the soils in the Măgherani Basin (soils of areas covered by woods were not investigated) 
The significance of calcium carbonate is especially relevant in the case of the slopes with southern, southwestern and western orientation, where it is found mostly on or near the surface. These sunny slopes have strong insolation; long dry periods are frequent, especially in July and August, when the biological activity of the soils virtually ceases. In this case, the $\mathrm{CO}_{2}$ content of the soil air is almost the same as that of the atmosphere, i.e. much smaller than in those soils characterized by a high grade of biological activity. In the course of a heavy downpour following such a dry period, the soil becomes saturated rapidly; the balance between the $\mathrm{CaCO}_{3}$ content and the soil moisture breaks rapidly while the low $\mathrm{CO}_{2}$ content remains.

Such conditions result in the increase of the $\mathrm{pH}$ of the soil causing the occurrence of excess negative charge along the edges of the clay particles. Therefore, they start to dissociate and push each other away (Schuylenborgh, 1972) [4].

Generally, this state remains for a short period of time, maybe only for a couple of hours. If this relatively short period coincides with the presence of a factor triggering a landslide (e.g., overload on a slope), the landslide may take place. Such coincidence can occur several times in a decade. Based on the above, it can be stated that low shear strength and low cohesion conditions, which can result in the formation of slumps, may occur due solely to the chemical processes taking place in the interior of the rocks.

\section{References}

[1] Chleborad, A. F., Baum, R. L. and Godt, J. P. (2006), Rainfall thresholds for forecasting landslides in the Seattle, Washington, Areaexceedance and probability. U.S. Geological Survey Open-File Report 2006-1064.

[2] Chung C. F., Fabbri A. G. (1999), Probabilistic prediction model for landslide hazard mapping. Photogrammetric Engineering and Remote Sensing 65: 1389-99.

[3] Coe, J. A., Michael, J. A., Crovelli, R. A., Savage, W. Z., Laprade, W. T., Nashem, W. D. (2004), Probabilistic assessment of precipitationtriggered landslides using historical records of landslide occurrence, Seattle, Washington. Environmental and Engineering Geoscience 10 (2), $103-122$. 
[4] Schuylenborgh, J. van (1972), Short introduction to the physico-chemical aspects of weathering and soil formation. Lecture notes I.T.C. Enschede.

[5] Montgomery, D. R., Sullivan, K., and Greenberg, H. M. (1998), Regional test of a model for shallow landsliding. Hydrological Processes 12: 94355 .

[6] Swanson, F. J. and Dryness, C. T. (1975), Impact of clear-cutting and road construction of soil erosion by landslides in the western Cascade Range, Oregon. Geology 3: 393-6.

[7] Ujvari, J., Buz, V. (1973), Perioade caracteristice de supraumectare a apelor subterane şi procesele gravitaţionale de versant, Studia Univ. Babeş-Bolyai, seria Geographia, fasc. 2, Cluj-Napoca.

[8] Varnes, D. J. (1984), Landslide Hazard Zonation: A Review of Principles and Practice. Paris, UNESCO Press, 63 pp.

[9] Zezere, J. L., Trigo, R. M., and Trigo, I. F. (2005), Shallow and deep landslides induced by rainfall in the Lisbon region (Portugal): assessment of relationships with the North Atlantic Oscillation, Nat. Hazards Earth Syst. Sci., 5, 331-344. 